\title{
Identification of the estrogen receptor GPER in neoplastic and non-neoplastic human testes
}

Vittoria Rago ${ }^{1}$, Francesco Romeo ${ }^{2}$, Francesca Giordano ${ }^{1}$, Marcello Maggiolini ${ }^{3}$ and Amalia Carpino ${ }^{1 *}$

\begin{abstract}
Background: Estrogen signaling is mediated by estrogen receptor beta isoforms in normal and neoplastic human testes. Recently, a G-protein-coupled-receptor (GPER) has been suggested as being involved in rapid responses to estrogens in different normal and tumor cells.

Methods: This study investigated the GPER expression in paraffin-embedded samples from non neoplastic and neoplastic human testes (sex-cord stromal and germ cell tumors) by immunohistochemical and Western Blot analyses.
\end{abstract}

Results: In control testes, a positive GPER immunoreactivity was detected in Leydig and in Sertoli cells while all germ cells were immunonegative. Furthermore, neoplastic cells of the Sertoli cell tumor, Leydig cell tumor, seminoma and embryonal carcinoma samples were all immunopositive. The immunoblots of testis extracts confirmed the results.

Conclusions: These findings suggest that GPER could mediate estrogen signaling in both normal and transformed somatic cells of human testis, but they reveal a differential expression of the novel estrogen receptor in non neoplastic and neoplastic germ cells.

\section{Background}

Estrogens exert their pleiotropic and tissue-specific effects on target cells through the differential expression of the classical estrogen receptors (ERs), ER $\alpha$ and ER $\beta$, which mediate both genomic and rapid signaling events $[1,2]$. In addition, estrogens induce rapid non-genomic responses from membrane-associated receptors such as growth factor receptors and $G$ protein-coupled receptors [3]. In the last years, a member of the 7-transmembrane G protein-coupled receptor family, GPR30, has been identified as a candidate to promote estrogen action in target cells [4-6] and different investigations have reported the expression of this novel estrogen receptor in a large variety of cell types [7]. Furthermore, GPR30 has been shown to have estrogen-binding affinity and to mediate estrogen-signal transduction events like calcium mobilization, kinase activation [5] and rapid transcriptional activation of early genes [8]. Therefore, despite some controversies regarding its biological role [9], GPR30 is now widely recognized as an estrogen receptor,

\footnotetext{
* Correspondence: am_carpino@yahoo.it

'Department of Cell Biology, Faculty of Pharmacy, University of Calabria, Italy Full list of author information is available at the end of the article
}

with the new acronym G-protein coupled estrogen receptor GPER, by the International Union of Basic and Clinical Pharmacology [10]

In the human, GPER (GPR30) has been detected $\mathrm{n}$ heart, lung, liver, intestine, ovary, prostate, kidney, brain [11]. In addition, GPER (GPR30)has been also evidenced in neoplastic tissues from breast, endometrial and ovary cancers [12-14] as well as in breast [15-17], endometrial $[18,19]$ ovarian [20] and thyroid carcinoma cells lines [21]. However, the association of the novel estrogen receptor with human cancer has only recently begun to be defined.

A large body of data indicated that estrogens regulate testis physiology [1] and they are also involved in male gonadic diseases, including cancer [22,23]. However, GPER signaling in human testes is still scarcely known. Therefore, the aim of this study was to investigate the pattern of GPER cellular distribution in non neoplastic and neoplastic human testes.

\section{Methods \\ Patients}

The investigation was performed on formalin-fixed and paraffin-embedded testis tissues from 20 caucasian male

\section{C)


patients: 3 patients with sex-cord stromal tumors (2 Leydig cell tumor and 1 Sertoli cell tumor) (ages from 25 to 31 years) and 17 patients with testicular germ cell tumors (10 seminoma and 7 embryonal carcinoma) (ages from 20 to 35 years) undergoing to therapeutic orchidectomy. Non neoplastic testicular tissues were obtained from 3 caucasian male patients ( ages from 29 to 36 years) showing testes with a granulomatous lesion. The archival cases were provided by the Pathologic Anatomy Unit (Annunziata Hospital, Cosenza, Italy). The ethical committee members of the University of Calabria approved the investigation programme.

\section{Histopathological analysis}

Morphological studies were carried out by HaematoxylinEosin staining.

\section{Chemicals and antibodies}

The reagents were purchased from Sigma Aldrich (Milan, Italy), unless otherwise indicated.

Anti-GPR30 (GPER) primary antibody was rabbit polyclonal LS-A4271(MBL International Corporation, Woburn, MA, USA) which recognizes epitope mapped at the $3^{\text {rd }}$ extracellular domain of human GPR30. Antihuman GATA- 4 was goat polyclonal C-20 (Santa Cruz Biotechnology, Santa Cruz, CA ). Rabbit polyclonal anti $\beta$-actin (Santa Cruz Biotechnology, Ca, USA) was also used as loading control. Biotinylated goat-anti-rabbit IgG (Vector Laboratories, INC, Burlingame, CA), biotinylated rabbit- anti -goat (Vector Laboratories, INC, Burlingame, CA), goat anti-rabbit horseradish peroxidase conjugated IgG (Amersham, USA ) were used as secondary antibodies.

\section{Immunohistochemical analysis}

Paraffin embedded sections, $5 \mu \mathrm{m}$ thick, were mounted on slides precoated with poly-lysine, and then they were deparafinized and dehydrated (7-8 serial sections). Immunohistochemical experiments were performed after heatmediated antigen retrieval. Hydrogen peroxide (3\% in distilled water) was used, for 30 minutes, to inhibit endogenous peroxidase activity while normal goat serum (10\% ) was utilised, for 30 minutes, to block the non-specific binding sites. Immunodetection was carried out using anti-GPR30 (GPER) (1:100) primary antibody at $4^{\circ} \mathrm{C}$ overnight. Then, a biotinylated goat-anti-rabbit IgG was applied (1:600) for 1 hour at RT, followed by the avidinbiotin-horseradish peroxidase complex (ABC/HRP) (Vector, Laboratories, CA, USA). Immunoreactivity was visualized by using the diaminobenzidine chromogen (DAB) (Zymed Laboratories, CA, USA). Testis sections were also counterstained with haematoxylin. The primary antibody was replaced by normal rabbit serum in negative control sections. Absorption controls have utilised primary antibodies preabsorbed with an excess $(5 \mathrm{nmol} / \mathrm{ml})$ of the purified blocking peptide (MBL International Corporation, Woburn, MA, USA), at $4^{\circ} \mathrm{C}$ for 48 hours. Breast cancer tissue was used as positive control.

With the aim to identify the Sertoli cells, sections of control testes were also subjected to the procedure outlined above using anti-human GATA- 4 (1: 50) as primary antibody.

\section{Scoring system}

The immunostained slides of tumour samples were evaluated by light microscopy using the Allred Score [24], which combines a proportion score and an intensity score. A proportion score was assigned representing the estimated proportion of positively stained tumor cells $(0=$ none; $1=1 / 100 ; 2=1 / 100$ to $<1 / 10 ; 3=1 / 10$ to $<1 / 3 ; 4=1 / 3$ to $2 / 3 ; 5=>2 / 3$ ). An intensity score was assigned by the average estimated intensity of staining in positive cells $(0=$ none; $1=$ weak; $2=$ moderate; $3=$ strong). Proportion score and intensity score were added to obtain a total score that ranged from 0 to 8 . A minimum of 100 cells were evaluated in each slide. Six to seven serial sections were scored in a blinded manner for each sample. The one-way ANOVA was used to evaluate the differences in the scores between tumor and control samples.

\section{Protein extraction}

Protein extraction from formalin-fixed paraffin-embedded sections was carried out according to Ikeda [25]. Briefly, $50 \mu \mathrm{m}$ testis sections were deparaffinized in xylene, dehydrated in graded ethanol, immersed in distilled water, and air dried. Then, the selected area was recovered from the glass slides, further it was cut into small pieces and placed in Eppendorf tubes. Two hundred $\mu$ l of RIPA buffer, $\mathrm{pH}$ 7,6 (1 M NaH${ }_{2} \mathrm{PO}_{4}, 10 \mathrm{mM} \mathrm{Na} \mathrm{HPO}_{4}, 154 \mathrm{mM} \mathrm{NaCl}, 1 \%$ Triton X-100, $12 \mathrm{mM} \mathrm{C}_{24} \mathrm{H}_{39} \mathrm{O}_{4} \mathrm{Na}, 0,2 \% \mathrm{NaN}_{3}, 0,95 \mathrm{mM}$ $\mathrm{NaF}, 2 \mathrm{mM}$ PMSF, $50 \mathrm{mg} / \mathrm{ml}$ aprotinin, $50 \mathrm{mM}$ leupeptin) containing $0,2 \%$ SDS, was added to each tube and the contents were incubated at $100^{\circ} \mathrm{C}$ for 20 minutes, followed by incubation at $60^{\circ} \mathrm{C}$ for 2 hours. After incubation, tissue lysates were centrifuged at $15,000 \times \mathrm{g}$ for 20 minutes at $4^{\circ} \mathrm{C}$ and the supernatants were stored at $-80^{\circ} \mathrm{C}$ until biochemical analysis.

\section{Western blot analysis}

Tissue lysates were quantified using Bradford protein assay reagent [26]. Equal amounts of protein $(50 \mu \mathrm{g})$ were boiled for 5 minutes, separated under denaturing conditions by SDS-PAGE on $10 \%$ polyacrylamide Tris-glycine gels and electroblotted to nitrocellulose membrane. Non-specific sites were blocked with $5 \%$ non fat dry milk in $0.2 \%$ Tween-20 in Tris-buffered saline (TBS-T) for 1 hour at RT and incubated overnight with anti-GPR30 (GPER) $(1: 500)$, anti- $\beta$ actin $(1: 1000)$ primary antibodies. The 
antigen-antibody complexes were then detected by incubation of the membranes for 1 hour at RT with the horseradish peroxidase-conjugated secondary antibodies (1:7000). The bound secondary antibodies were located with the ECL Plus Western blotting detection system (Amersham, USA) according to the manufacturer's instruction. Each membrane was exposed to the film for 2 minutes. Breast cancer tissue were used as positive control. Negative controls were prepared using tissue lysates, where antigens were previously removed by pre-incubation with specific antibodies (1 hour at room temperature) and subsequently immunoprecipitated with protein $\mathrm{A} / \mathrm{G}$ -agarose.

WB analysis was repeated 3 times for each sample

\section{Results \\ Morphological study \\ Control testes}

The unaltered regions of non neoplastic testes were used as control samples. They displayed typical seminiferous tubules showing active spermatogenesis. In the basal compartment of seminiferous tubules, Sertoli cells were identified for their typical characteristics: large irregular nuclei with distinct nucleoli and extensive cytoplasmic processes extending from the basement membrane to the lumen of the tubule. Furthermore, Leydig cells were observed in the interstitial tissue (Figure 1).

In addition to morphological analysis, identification of Sertoli cells was supported by their dark nuclear staining of GATA-4, a Sertoli cell marker [27]. Figure 2 shows a representative comparison between the immunostainings of GATA-4 (2 A) and GPER (2 B) in two serial sections of control testis. The same result was observed in all control samples.

\section{Tumor testes}

Sex cord-stromal tumors Leydig cell tumors revealed large, vacuolated Leydig cells arranged in multiple clusters. In the Sertoli cell tumor a pattern of diffuse tubular differentiation was observed, while neoplastic cells showed pale and vacuolated cytoplasms with dysvolumetric and pyknotic nuclei (Figure 3)

\section{Testicular germ cell tumors (TGCTs)}

Pure seminoma samples showed uniform populations of round/polygonal big neoplastic cells with well-defined borders. These cells were arranged in diffuse sheets separated by thin septae. Extensive leukocyte infiltrations were observed in all samples (Figure 3). Pure embryonal carcinomas revealed nodular areas surrounded by connective tissue and showing large neoplastic cells with ill-defined borders, big nuclei, pale cytoplasms (Figure 3)

\section{Immunohistochemistry}

The specificity of the GPR30 (GPER) antibody (LS-A4271), used in the present study, was assessed in previous works knocking down the protein expression by a shGPR30 (GPER) [19,28-30]. However, similar results were obtained utilizing the rabbit polyclonal anti-GPR30 (GPER) primary antibody (sc-48524) from Santa Cruz (Santa Cruz Biotechnology, Santa Cruz, CA ) $[4,31]$.

\section{Control testes}

GPER immunoreactivity was detected in the cytoplasm of Leydig cells and Sertoli cells of the control testes while all germ cells were unlabelled (Figure 1: A, A1, B, B1, C, C1).

\section{Tumor testes}

A positive GPER immunostaining was revealed in neoplastic cell cytoplasm of Leydig and Sertoli cell tumors (Figure 4: A-B Leydig cell tumors; C Sertoli cell tumor) as well as in all seminoma and embryonal carcinoma samples, while the leukocytes were immunonegative. (Figure 5: A seminoma, B embryonal carcinoma). Table 1 shows the intensity staining scores of GPER in tumor and control samples. As expected, a strong GPER signal was detected in the breast cancer tissue, used as positive control (5 C). Furthermore, negative controls (data not shown) and absorption controls (inserts) were all immunonegative.

\section{Western blot analysis}

The immunoblots of testis extracts showed a single band of $\sim 42 \mathrm{kDa}$ in control (Figure 6: lanes $C$ ) and in testicular germ cell tumor samples (Figure 6: lanes $S, E C$ ) A band at the same mobility was observed in the positive control (breast cancer) (Figure 6: lane +), while the negative control lane was unlabelled (Figure 6: lane -). Similar results were obtained from all control and TGCT samples. The quantity of Leydig cell tumor and Sertoli cell tumor samples was not sufficient to perform the protein extraction for Western blot analysis.

\section{Discussion}

It is well known that estrogens regulate growth, differentiation and function of normal human testes through the mediation of estrogen receptor beta isoforms (ER $\beta 1 / E R \beta 2)$ $[1,32]$. In addition, previous studies indicated that the classical ERs are also involved in the responses to estrogens in testicular germ cell tumors $[33,34]$ as well as in Leydig cell tumor [35].

The present study identified GPER in non neoplastic and neoplastic cells of human male gonads. Particularly, the "novel" estrogen receptor was localized in the cytoplasm of gonadic cells, according to previous observations showing its presence in the endoplasmic reticulum of different cell types $[4,36]$.

Concerning non neoplastic testes, our investigation evidenced GPER exclusively in somatic cells, i.e. in interstitial Leydig cells and in intratubular Sertoli cells. Particularly, Sertoli cell identification inside seminiferous tubules was supported by the dark nuclear GATA-4 

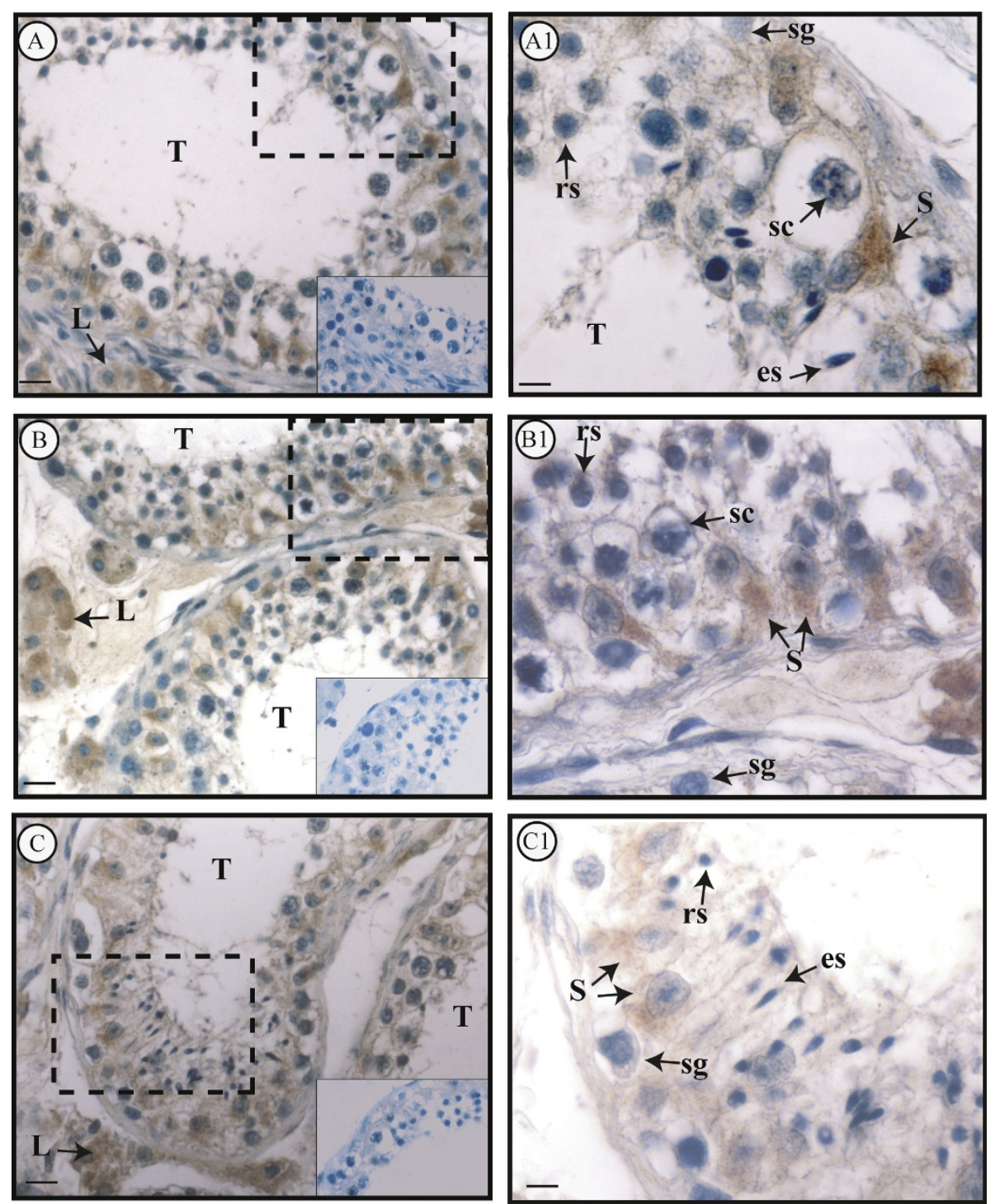

Figure 1 Immunolocalization of GPER in control testes. A-C: Positive GPER immunoreactivity in the somatic cell cytoplasm of the three samples. A1-C1: Higher magnifications of testicular areas surrounded by the dashed lines in A-C. L, Leydig cell; T, seminiferous tubule; $\mathbf{S}$, Sertoli cell; sg, spermatogonium; sc, spermatocyte; rs, round spermatid; es, elongated spermatid. Inserts: absorption controls. Scale bars $=12.5 \mu m$ (A, B, C), $5 \mu \mathrm{m}(\mathrm{A} 1, \mathrm{~B} 1, \mathrm{C} 1)$.

staining; in fact GATA-4 is a transcription factor expressed in Sertoli cells but not in germ cells of adult mammals [27]. On the contrary, in the same samples, GPER immunoreactivity was not observed in germ cells. Therefore, comparing the cellular distribution of GPER between human and rodent testes, it appears that GPER expression is similar in somatic cells but not in germ cells. In fact, GPER (GPR30) has been found in rat Sertoli cells [37] but also in mouse spermatogonia GC-1 cell line [38], in rat pachytene spermatocytes and in rat round spermatids $[39,40]$. It is interesting to note that a similar species- specific expression has been reported for ER $\alpha$ which has been shown in rat testes[32,41,42] but not in human testes.

Noteworthy, the present study revealed the expression of GPER in testis tumors deriving from both somatic and germ testicular cells. Concerning testicular stromal neoplasms, we identified for the first time, GPER in Leydig cell tumor and Sertoli cell tumor, expanding the limited knowledge of estrogen signaling mechanism in these rare neoplasms. Therefore, the present investigation demonstrated that GPER could mediate estrogen action in both normal and transformed somatic cells of human testes. Conversely, our previous study has evidenced a differential expression pattern of the classical ERs in human normal 

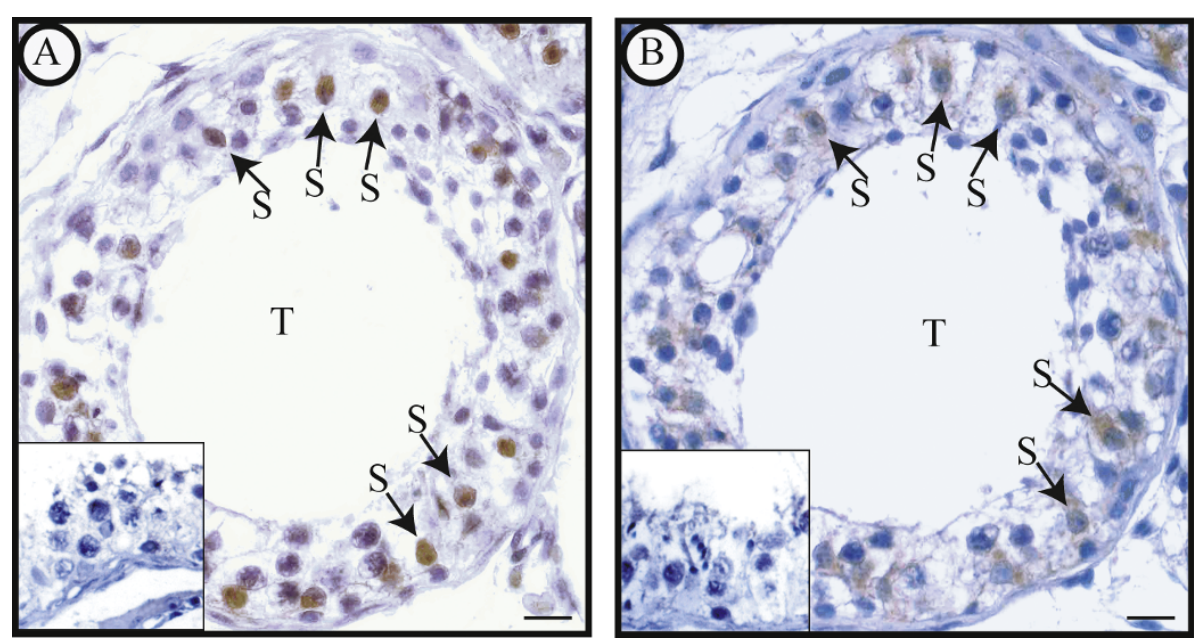

Figure 2 Immunostaining of GATA-4 and GPER in control testis (serial sections). A. Dark GATA-4 nuclear immunoreactivity in Sertoli cells (arrows). B. Dark GPR30 staining in the cytoplasm of Sertoli cells (arrows). Scale bars $=12.5 \mu \mathrm{m}$.

and neoplastic Leydig cells with the exclusive presence of $\mathrm{ER} \alpha$ in tumor cells, which could amplify estrogen signaling and could contribute to tumor growth [35]

Furthermore, the present investigation demonstrated the GPER expression in neoplastic cells of seminoma and embryonal carcinoma. These are testicular germ cell tumors (TGCTs) deriving from abnormal gonocytes which arrest their differentiation and undergo a malignant transformation [43-45]. Our previous paper has demonstrated that ER $\beta 1$ and ER $\beta 2$ could mediate estrogen action in early and late seminoma and embryonal carcinoma cells [34] as well as in germ cells of control testes. Conversely, the present results revealed GPER in the transformed cells of seminoma and embryonal carcinoma but not in control

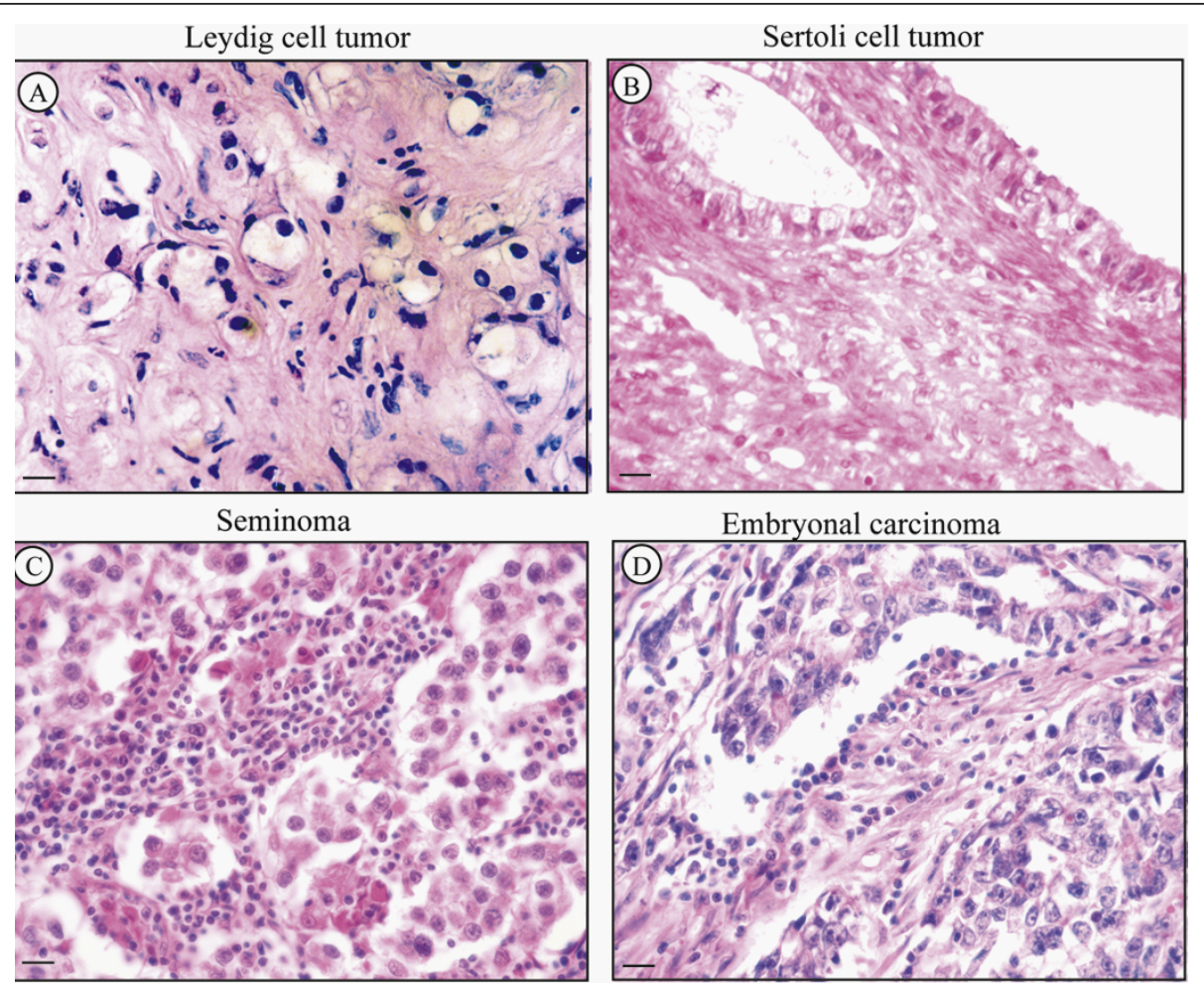

Figure 3 Haematoxylin -Eosin staining of representative human testicular tumors. A. Leydig cell tumor. B. Sertoli cell tumor. C. Seminoma. D. Embryonal carcinoma. Scale bars $=12.5 \mu \mathrm{m}$. 


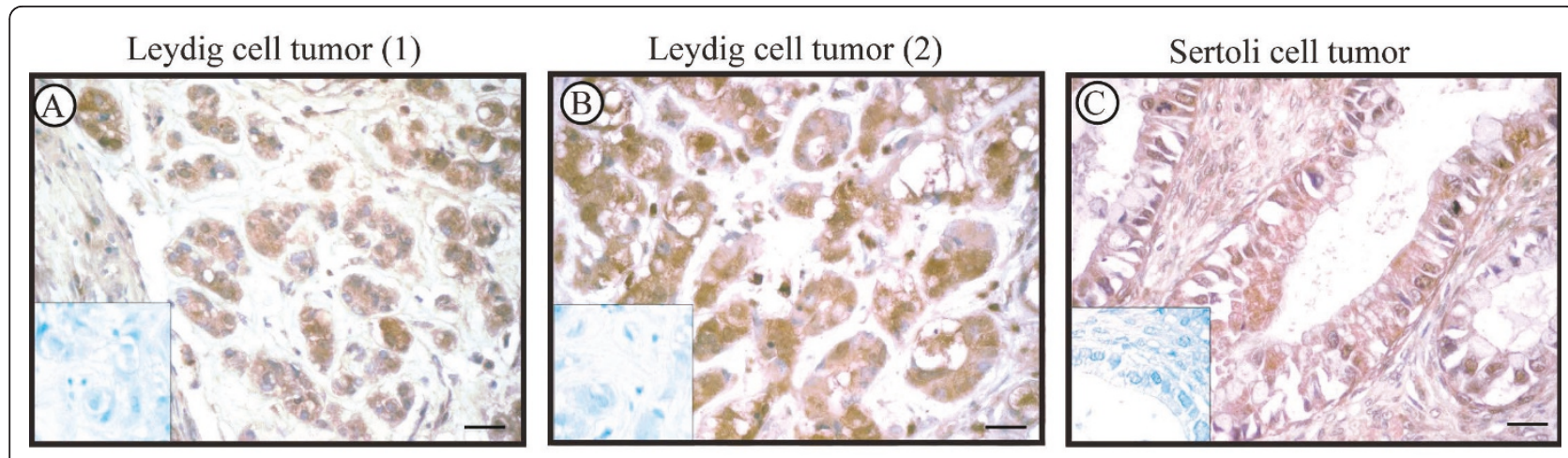

Figure 4 Immunolocalization of GPER in sex cord- stromal testis tumors. A-B: Leydig cell tumors, C:Sertoli cell tumor. Inserts: absorption controls. Scale bars $=12.5 \mu \mathrm{m}$.

germ cells. These findings might suggest a possible link between GPER and testis carcinogenesis. In this regard, a very recent study [46] have reported the GPR30(GPER) expression in TGCTs evidencing an increasing expression of the novel estrogen receptor during the tumor development. The authors have suggested GPR30 as a potential therapeutic target.

Interestingly, it has been reported that estrogens can contribute to human germ cell cancer proliferation (JKT1 seminoma cell line) through a membrane non classical ER [47]. The same authors have also evidenced that the xenoestrogen bisphenol A can promote human seminoma cell proliferation activating PKA and PKG via a membrane G-protein-coupled estrogen receptor $[48,49]$
Different studies have revealed that GPER and the classical ERs can be co-expressed in some cells, so synergic/antagonist interactions can be expected on the basis of the cellular contexts. In this regard, a recent paper have reported the co-expression of ER $\beta$ and (GPR30)GPER in uterine carcinoma together with their significant correlation during tumor progression [50]. In the present and our previous studies [34,35] we evidenced the expression of either the classical ERs or GPER in sex-cord stromal and germ cell testicular tumors, but a possible coordinate regulation or a cross talk between these estrogen receptors will be clarified by future investigations performed on neoplastic samples in early-advanced stages of the disease.

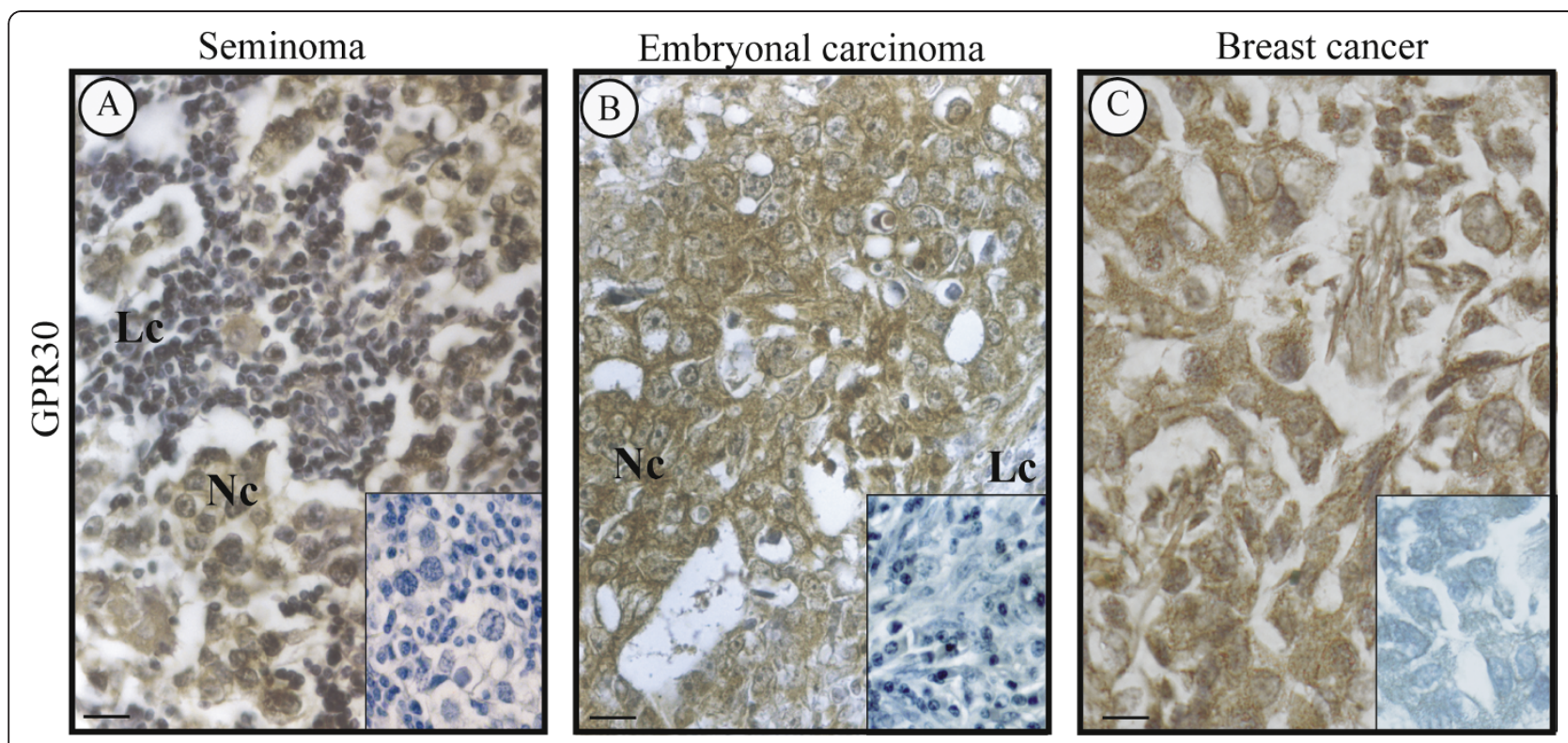

Figure 5 Immunolocalization of GPER inTGCTs. A: seminoma. B: embryonal carcinoma. Nc: neoplastic cells. Lc: lymphocytes. C: breast cancer (positive control). Inserts: absorption controls. Scale bars $=12.5 \mu \mathrm{m}$. 
Table 1 Allred score of GPER in tumor and control testicular cells

\begin{tabular}{|c|c|c|c|c|c|}
\hline \multicolumn{2}{|c|}{ Germ cell tumors } & \multirow{2}{*}{\multicolumn{2}{|c|}{$\begin{array}{l}\text { Stromal tumors } \\
\text { Leydig cell tumor }\end{array}$}} & \multicolumn{2}{|c|}{ Control testes } \\
\hline \multicolumn{2}{|c|}{ Seminoma } & & & Germ ce & \\
\hline patient 1 & 7 & patient 1 & 7 & control 1 & 0 \\
\hline patient 2 & 6 & patient 2 & 6 & control 2 & 0 \\
\hline patient 3 & 7 & \multicolumn{2}{|c|}{ Sertoli cell tumor } & control 3 & 0 \\
\hline patient 4 & 7 & patient 1 & 7 & Leydig & \\
\hline patient 5 & 7 & & & control 1 & 7 \\
\hline patient 6 & 5 & & & control 2 & 7 \\
\hline patient 7 & 7 & & & control 3 & 7 \\
\hline patient 8 & 6 & & & Sertoli & \\
\hline patient 9 & 7 & & & control 1 & 7 \\
\hline patient 10 & 5 & & & control 2 & 7 \\
\hline \multicolumn{2}{|c|}{ Embryonal carcinoma } & & & control 3 & 7 \\
\hline patient 1 & 6 & & & & \\
\hline patient 2 & 6 & & & & \\
\hline patient 3 & 5 & & & & \\
\hline patient 4 & 5 & & & & \\
\hline patient 5 & 5 & & & & \\
\hline patient 6 & 6 & & & & \\
\hline patient 7 & 6 & & & & \\
\hline
\end{tabular}

Immunostainig score: Total score = Proportion score+Intensity score (range 08) TGCT versus control $=p<0.001$ (one-way Anova test)

\section{Conclusions}

The present investigation identified the cellular expression of $G$ protein-coupled estrogen receptor (GPER) in non neoplastic and neoplastic human testes. GPER was detected exclusively in Leydig cells and Sertoli cells of non neoplastic testes while it was observed in the transformed cells of Leydig cell tumor, Sertoli cell tumor, seminoma and embryonal carcinoma samples. These findings suggest

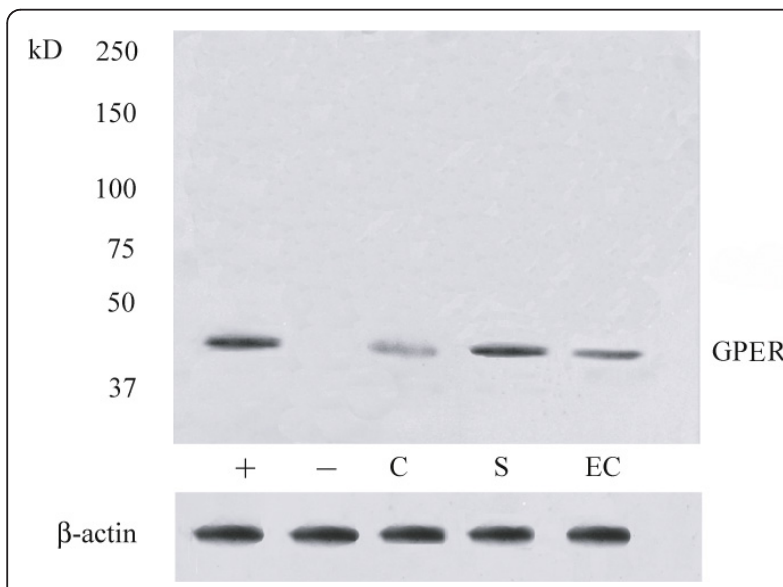

Figure 6 GPER immunoblots of representative protein extracts from testicular samples. Positive control (lane + ), negative control (lane -), control testis (lane $C$ ), seminoma (lane $S$ ), embryonal carcinoma (lane EC). $\beta$-actin serves as a loading control. Numbers on the left correspond to molecular weight markers. that GPER could mediate estrogen signaling in both normal and transformed somatic cells of the human testis, but at the same time these results reveal a differential expression of the novel estrogen receptor in normal and neoplastic germ cells.

\section{Acknowledgements}

The authors thank prof. Antonietta Martire for the English reviewing of this manuscript. This work was supported by MIUR (ex-60\% -2008).

\section{Author details}

${ }^{1}$ Department of Cell Biology, Faculty of Pharmacy, University of Calabria, Italy. ${ }^{2}$ Pathologic Anatomy Unit, Annunziata Hospital, Cosenza, Italy. ${ }^{3}$ Department of Pharmaco-Biology, Faculty of Pharmacy, University of Calabria, Italy.

\section{Authors' contributions}

VR carried out immunohistochemical expriments and data analysis. FR the author responsible for histoplathological diagnosis. FG carried out Western blot analysis. MM the author responsible for a critical revision of the manuscript. AC the author responsible for conception, design, analysis and interpretation of data as well as of drafting manuscript. All authors read and approved the final manuscript.

\section{Competing interests}

The authors declare that they have no competing interest.

Received: 27 June 2011 Accepted: 5 October 2011

Published: 5 October 2011

\section{References}

1. O'Donnell L, Robertson KM, Jones ME, Simpson ER: Estrogen and spermatogenesis. Endocr Rev 2001, 22:289-318.

2. Moriarty K, Kim KH, Bender JR: Estrogen receptor-mediated rapid signaling. Endocrinology 2006, 147(12):5557-5563.

3. Kampa M, Pelekanou V, Castanas E: Membrane-initiated steroid action in breast and prostate cancer. Steroids 2008, 73:953-956.

4. Revankar CM, Cimino DF, Sklar LA, Arterburn JB, Prossnitz ER: A transmembrane intracellular estrogen receptor mediates rapid cell signaling. Science 2005, 307:1625-1630.

5. Prossnitz ER, Arterburn JB, Smith HO, Oprea TI, Sklar LA, Hathaway HJ: Estrogen signaling through the transmembrane $\mathrm{G}$ protein-coupled receptor GPR30. Ann Rev Physiol 2008, 70:165-190.

6. Prossnitz ER, Barton M: Signaling, physiological functions and clinical relevance of the $\mathrm{G}$ protein-coupled estrogen receptor GPER. Prostaglandins Other Lipid Mediat 2009, 89(3-4):89-97.

7. Prossnitz ER, Maggiolini M: Mechanisms of estrogen signaling and gene expression via GPR30. Mol Cell Endocrinol 2009, 308(1-2):32-38.

8. Maggiolini M, Vivacqua A, Fasanella G, Recchia AG, Sisci D, Pezzi V, Montanaro D, Musti AM, Picard D, Andò S: The G protein-coupled receptor GPR30 mediates c-fos up-regulation by 17 beta-estradiol and phytoestrogens in breast cancer cells. J Biol Chem 2004, 279:27008-27016.

9. Levin ER: G protein-coupled receptor 30: estrogen receptor or collaborator? Endocrinology 2009, 150(4):1563-1569.

10. Maggiolini M, Picard D: The unfolding stories of GPR30, a new membrane-bound estrogen receptor. J Endocrinol 2010, 204(2):105-114.

11. Olde B, Leeb-Lundberg LM: GPR30/GPER1: searching for a role in estrogen physiology. Trends Endocrinol Metab 2009, 20(8):409-416.

12. Filardo EJ, Graeber CT, Quinn JA, Resnick MB, Giri D, DeLellis RA, Steinhoff MM, Sabo E: Distribution of GPR30, a seven membranespanning estrogen receptor, in primary breast cancer and its association with clinicopathologic determinants of tumor progression. Clin Canc Res 2006, 12(21):6359-66.

13. Smith HO, Leslie KK, Singh M, Qualls CR, Revankar CM, Joste NE, Prossnitz ER: GPR30: a novel indicator of poor survival for endometrial carcinoma. Am J Obstet Gynecol 2007, 196(4):386.e1-9, discussion 386.e9-11..

14. Smith HO, Arias-Pulido H, Kuo DY, Howard T, Qualls CR, Lee SJ, Verschraegen CF, Hathaway HJ, Joste NE, Prossnitz ER: GPR30 predicts poor survival for ovarian cancer. Gynecol Oncol 2009, 114(3):465-471. 
15. Filardo EJ, Quinn JA, Bland Kl, Frackelton AR: Estrogen-induced activation of Erk-1 and Erk-2 requires the G protein-coupled receptor homolog, GPR30, and occurs via trans-activation of the epidermal growth factor receptor through release of HB-EGF. Mol Endocrinol 2000, 14(10):1649-1660.

16. Albanito L, Sisci D, Aquila S, Brunelli E, Vivacqua A, Madeo A, Lappano R, Pandey DP, Picard D, Mauro L, Andò S, Maggiolini M: Epidermal growth factor induces $G$ protein-coupled receptor 30 expression in estrogen receptor-negative breast cancer cells. Endocrinology 2008, 149:3799-3808.

17. Pandey DP, Lappano R, Albanito L, Madeo A, Maggiolini M, Picard D: Estrogenic GPR30 signalling induces proliferation and migration of breast cancer cells through CTGF. EMBO J 2009, 28(5):523-532.

18. Vivacqua A, Bonofiglio D, Recchia AG, Musti AM, Picard D, Andò S, Maggiolini M: The G protein-coupled receptor GPR30 mediates the proliferative effects induced by 17beta-estradiol and hydroxytamoxifen in endometrial cancer cells. Mol Endocrinol 2006, 20:631-646.

19. Vivacqua A, Lappano R, De Marco P, Sisci D, Aquila S, De Amicis F, Fuqua SA, Andò S, Maggiolini M: G protein-coupled receptor 30 expression is up-regulated by EGF and TGF alpha in estrogen receptor alpha-positive cancer cells. Mol Endocrinol 2009, 23:1815-1826.

20. Albanito L, Madeo A, Lappano R, Vivacqua A, Rago V, Carpino A, Oprea TI, Prossnitz ER, Musti AM, Andò S, Maggiolini M: G protein-coupled receptor 30 (GPR30) mediates gene expression changes and growth response to 17beta-estradiol and selective GPR30 ligand G-1 in ovarian cancer cells. Cancer Res 2007, 67(4):1859-1866.

21. Vivacqua A, Bonofiglio D, Albanito L, Madeo A, Rago V, Carpino A, Musti AM, Picard D, Andò S, Maggiolini M: 17beta-estradiol, genistein, and 4-hydroxytamoxifen induce the proliferation of thyroid cancer cells through the g protein-coupled receptor GPR30. Mol Pharmacol 2006, 70:1414-1423

22. Li X, Nokkala E, Yan W, Streng T, Saarinen N, Wärri A, Huhtaniemi I, Santti R, Mäkelä S, Poutanen M: Altered structure and function of reproductive organs in transgenic male mice overexpressing human aromatase. Endocrinology 2001, 42(6):2435-42.

23. Sharpe RM: The 'oestrogen hypothesis'- where do we stand now? Int J Androl 2003, 26(1):2-15.

24. Allred DC, Harvey JM, Berardo M, Clark GM: Prognostic and predictive factors in breast cancer by immunohistochemical analysis. Mod Pathol 1998, 11:155-168.

25. Ikeda K, Monden T, Kanoh T, Tsujie M, Izawa H, Haba A, Ohnishi T, Sekimoto M, Tomita N, Shiozaki H, Monden M: Extraction and analysis of diagnostically useful proteins from formalin-fixed, paraffin-embedded tissue sections. J Histochem Cytochem 1998, 4:397-403.

26. Bradford MM: A rapid and sensitive method for the quantitation of microgram quantities of protein utilizing the principle of protein-dye binding. Anal Biochem 1976, 72:248-254.

27. Ketola I, Pentikäinen V, Vaskivuo T, Ilvesmäki V, Herva R, Dunkel L, Tapanainen JS, Toppari J, Heikinheimo M: Expression of transcription factor GATA-4 during human testicular development and disease. J Clin Endocrinol Metab 2000, 85(10):3925-3931.

28. Lappano R, Rosano C, De Marco P, De Francesco EM, Pezzi V, Maggiolini M: Estriol acts as a GPR30 antagonist in estrogen receptor-negative breast cancer cells. Mol Cell Endocrinol 2010, 320(1-2):162-170.

29. Madeo A, Maggiolini M: Nuclear alternate estrogen receptor GPR30 mediates 17beta-estradiol-induced gene expression and migration in breast cancer-associated fibroblasts. Canc Res 2010, 70(14):6036-6046.

30. Recchia AG, De Francesco EM, Vivacqua A, Sisci D, Panno ML, Ando' S, Maggiolini M: The $\mathrm{G}$ protein-coupled receptor 30 is up-regulated by hypoxia inducible factor-1 $\{$ alpha\} (HIF-1 \{alpha\}) in breast cancer cells and cardiomyocytes. J Biol Chem 2011, 286(12):10773-10782.

31. Filardo EJ, Quinn JA, Frackelton AR, Bland Kl: Estrogen action via the G protein-coupled receptor, stimulation of adenylyl cyclise and CAMPmediated attenuation of the epidermal growth factor receptor-to-MAPK signalling axis. Mol Endocrinol 2002, 16:70-84.

32. Carreau S, Hess RA: Oestrogens and spermatogenesis. Philos Trans $R$ Soc Lond B Biol Sci 2010, 365:1517-1535.

33. Pais V, Leav, Lau KM, Jiang Z, Ho SM: Estrogen receptor-beta expression in human testicular germ cell tumors. Clin Canc Res 2003, 9(12):4475-4482.

34. Rago V, Romeo F, Giordano F, Ferraro A, Andò S, Carpino A: Identification of ERbeta1 and ERbeta2 in human seminoma, in embryonal carcinoma and in their adjacent intratubular germ cell neoplasia. Reprod Biol Endocrinol 2009, 7:56.

35. Carpino A, Rago V, Pezzi V, Carani C, Andò S: Detection of aromatase and estrogen receptors (ERalpha, ERbeta1, ERbeta2) in human Leydig cell tumor. Eur J Endocrinol 2007, 157(2):239-44.

36. Revankar CM, Mitchell HD, Field AS, Burai R, Corona C, Ramesh C, Sklar LA, Arterburn JB, Prossnitz ER: Synthetic estrogen derivatives demonstrate the functionality of intracellular GPR30. ACS Chem Biol 2007, 2(8):536-534.

37. Lucas TF, Royer C, Siu ER, Lazari MF, Porto CS: Expression and Signaling of G Protein-Coupled Estrogen Receptor (GPER) in Rat Sertoli Cells. Biol Reprod 2010, 83(2):307-317.

38. Sirianni R, Chimento A, Ruggiero C, De Luca A, Lappano R, Andò S, Maggiolini $M$, Pezzi V: The novel estrogen receptor, $G$ protein-coupled receptor 30 , mediates the proliferative effects induced by 17 betaestradiol on mouse spermatogonial GC-1 cell line. Endocrinology 2008, 149:5043-5051.

39. Chimento A, Sirianni R, Delalande C, Silandre D, Bois C, Andò S, Maggiolini M, Carreau S, Pezzi V: 17-beta-estradiol activates rapid signaling pathways involved in rat pachytene spermatocytes apoptosis through GPR30 and ER alpha. Mol Cell Endocrinol 2010, 320:136-144.

40. Chimento A, Sirianni R, Zolea F, Bois C, Delalande C, Andò S, Maggiolini M, Aquila S, Carreau S, Pezzi V: Gper and ESRs are expressed in rat round spermatids and mediated oestrogen-dependent rapid pathways modulating expression of cyclin B1 and Bax. Int J Androl 2010.

41. Bois C, Delalande C, Nurmio M, Parvinen M, Zanatta L, Toppari J, Carreau S: Age-and cell-related gene expression of aromatase and estrogen receptors in the rat testis. J Mol Endocrinol 2010, 45(3):147-159.

42. Carreau S, Bois C, Zanatta L, Silva FR, Bouraima-Lelong H, Delalande C: Estrogen signaling in testicular cells. Life Sci 2011.

43. Looijenga $L H$, de Munnik $H$, Osterhuis JW: A molecular model for the development of germ cell cancer. Int J Canc 1999, 83(6):809-814.

44. Rajpert-de Meyts E, Hoei-Hansen CE: From gonocytes to testicular cancer: the role of impaired gonadal development. Ann N Y Acad Sci 2007, 1120:168-180.

45. Skakkebaek NE, Rajpert-De Meyts E, Jørgensen N, Main KM, Leffers H, Andersson AM, Juul A, Jensen TK, Toppari J: Testicular cancer trends as 'whistle blowers' of testicular developmental problems in populations. Int J Androl 2007, 30(4):198-204.

46. Franco R, Boscia F, Gigantino V, Marra L, Esposito F, Ferrara D, Pariante P, Botti G, Caraglia M, Minucci S, Chieffi P: GPR30 is overexpressed in postpuberal testicular germ cell tumors. Cancer Biol Ther 2011, 11(6):609-613.

47. Bouskine A, Nebout M, Mograbi B, Brücker-Davis F, Roger C, Fenichel P: Estrogens promote human testicular germ cell cancer through a membrane-mediated activation of extracellular regulated kinase and protein kinase A. Endocrinology 2008, 149(2):565-573.

48. Bouskine A, Nebout M, Brücker-Davis F, Benahmed M, Fenichel P: Low doses of bisphenol A promote human seminoma cell proliferation by activating PKA and PKG via a membrane G-protein-coupled estrogen receptor. Environ Health Perspect 2009, 117(7):1053-1058.

49. Chevalie RN, Bouskine A, Fenichel P: Bisphenol A promotes testicular seminoma cell proliferation through GPER, the G-protein-coupled estrogen receptor. Int I Canc 2011.

50. Huang GS, Gunter MJ, Ared RC, Li M, Arias-Pulido H, Prossnitz ER, Goldberg GL, Smith HO: Co-expression of GPR30 and ERb and their association with disease progression in uterine carcinosarcoma. Am J Obstet Gynecol 2010, 203:242.e1-5.

doi:10.1186/1477-7827-9-135

Cite this article as: Rago et al: Identification of the estrogen receptor GPER in neoplastic and non-neoplastic human testes. Reproductive Biology and Endocrinology 2011 9:135. 